
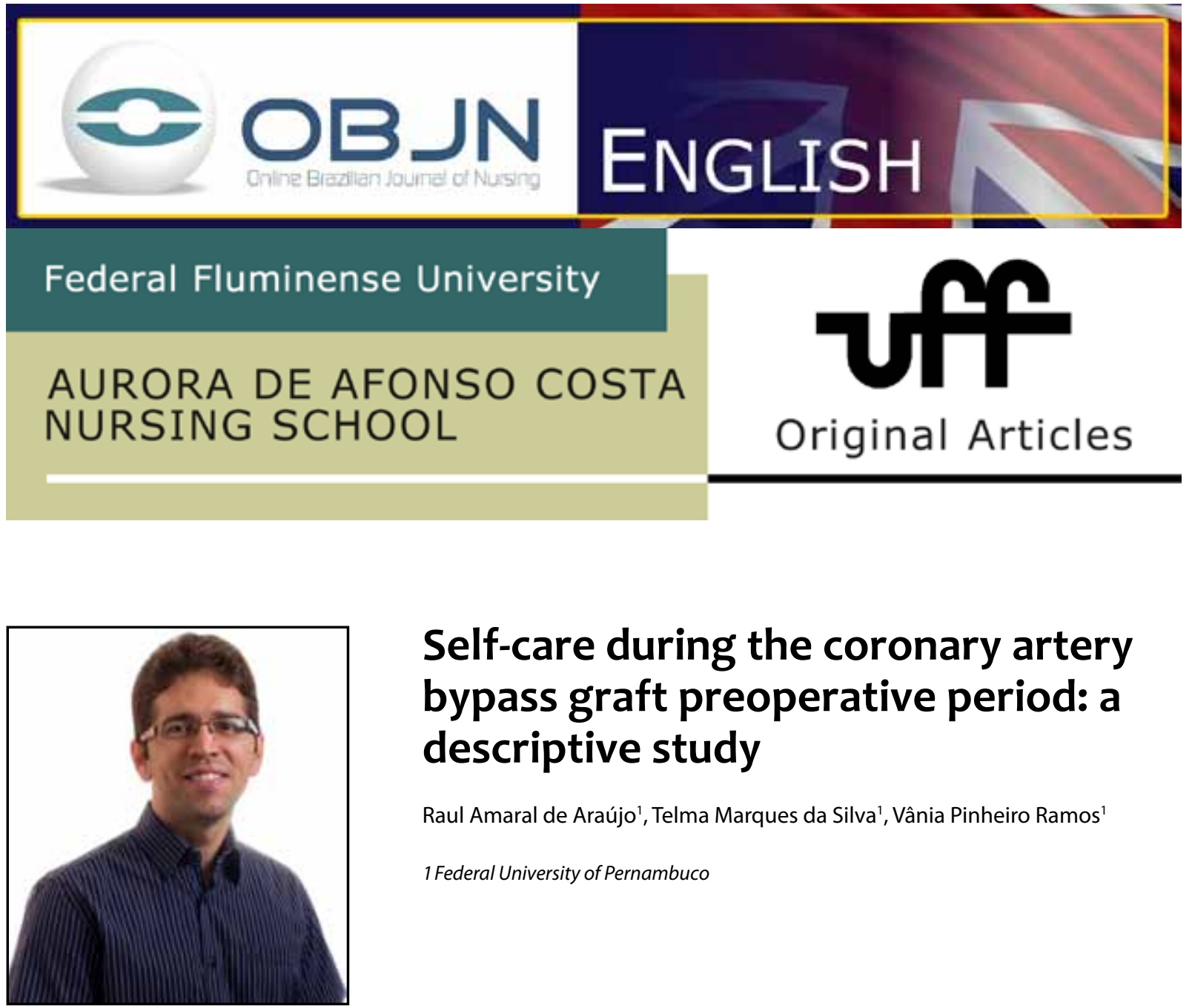

\title{
Self-care during the coronary artery bypass graft preoperative period: a descriptive study
}

\author{
Raul Amaral de Araújo', Telma Marques da Silva', Vânia Pinheiro Ramos' \\ 1 Federal University of Pernambuco
}

\section{ABSTRACT}

Aim: To relate the basic conditioning factors of self-care to the self-care capability of patients in the preoperative period of coronary artery bypass graft (CABG). Method: a descriptive, cross-sectional study, using the Self Care Theory as a reference. Data from 62 participants were collected through individual interviews. Tests were applied to analyze ratios comparing the means and using the Poisson regression model. Results: The self-care capability was $87.5 \%( \pm 10.5)$ and was related to income and the age of the participants. Discussion: the association between treatment and self-care capability may relate to an ability to adapt to, and cope with, cardiovascular problems that require surgical procedures. Conclusion: The application of Self-Care Theory is a possibility for patients in the CABG preoperative period. This strengthens the integration between research, theory and practice, and contributes to the definition and autonomy of the work process in nursing.

Keywords: Self-care; Nursing Theory; Pre-operative Care. 


\section{INTRODUCTION}

Self-care is an important practice related to non-communicable diseases (NCD) which requires the involvement of the affected individuals in the care for their own health. This requirement comes about due to the complexity and sometimes the chronicity of the health-disease process of these conditions, as well as from the search for a satisfactory quality of life $(\mathrm{QOL})^{(1)}$.

The search for QOL is a matter that can be studied from different points of view. In this aspect, and regarding the NCD care measures, there is coronary artery bypass grafting (CABG), a standard surgical procedure performed to improve the prognosis of individuals affected by ischemic cardiovascular diseases, which promotes the need for the practice of self-care ${ }^{(2-3)}$.

Faced with $C A B G$ and the aspects related to self-care, nursing staff, in the CABG preoperative stage, have been active in preventing complications that may arise from the surgical procedure. This action is also based on health education in order to empower individuals about issues related to self-care ${ }^{(4)}$.

In this context, self-care can be learned throughout life, and is characterized as an action initiated and executed by individuals for their own benefit, according to the theoretical model of Dorothea Orem ${ }^{(5-6)}$.

This model consists of three inter-related theoretical constructs: the Theory of Self-Care, the Theory of Self-Care Deficit and the Nursing System Theory ${ }^{(5-6)}$, all of which can support nursing care in the CABG preoperative period. They can also provide support for the prevention of surgical complications, guiding the search for weaknesses in the process and for the empowerment of self-care practices ${ }^{(4-6)}$.

The empowerment of such practices requires a knowledge and recognition of the self-care basic conditioning factors (BCF), and the self-care capability (SCC) of individuals in the CABG preoperative period $^{(4-6)}$

The BCF influence on the capability for effective self-care includes characteristics such as age, gender, socio-cultural aspects and family support. SCC, on the other hand, is described as the ability that individuals have to voluntarily and deliberately engage in actions directed to their own health and well-being(6).

A study of both aspects can promote health education actions favoring self-confidence and self-knowledge, that are necessary for the CABG perioperative period ${ }^{(4-6)}$. Thus, this study aims to relate the $B C F$ to the $S C C$ of individuals in the $C A B G$ preoperative period.

\section{METHOD}

This is a descriptive, cross-sectional study which adopts a quantitative approach ${ }^{(7)}$, undertaken in the Cardiology Emergency Room at the University Hospital of Pernambuco, located in Recife / PE, a main reference for cardiology health care in the North and Northeast regions of Brazil.

The study population consists of individuals hospitalized during the CABG preoperative period. The sample size was determined as 62 participants through sample calculation for the proportion of finite population studies, based on a previous study at research site ${ }^{(8)}$. All accessible individuals who met the following inclusion criteria were enrolled: those who were undergoing CABG for the first time; both genders; and aged between 50 and 70 years of age (the predominant age distribution in the population surveyed) were considered elective ${ }^{(8)}$. Patients with surgery scheduled for the day of the data collection; who had neurological or muscular damage; were undergoing psychotropic medical treatment; who had communication difficulties or inability to respond to the questionnaires while collecting data, were excluded from the study. 
Data were collected between March and August 2013, through individual interviews undertaken in a private environment. We developed a instrument based on Self Care Theory which was used as a theoretical and methodological framework for this study ${ }^{(6)}$. This theory is one of three pillars that make up the theoretical model proposed by Dorothea Orem which has self-care as a central concept, and which includes the BCF and the $\mathrm{SCC}^{(6)}$.

Thus, the following data about BCF were collected: age, gender, self-reported race, marital status, education, employment status, individual and family monthly income, number of family members, and socioeconomic status ${ }^{(6)}$.

Socioeconomic class was defined using the National Economic Classification Criteria, which estimates the purchasing power of the individual through the amount of owned items and the household head's '..educational level... Eight possible cutoff groups were considered as follows: A1 (highest status), A2, B1, B2, C1, C2, D and E (lowest status) $^{(9)}$.

During data collection, an instrument to assess the SCC entitled the Appraisal of Self-Care Agency Scale (ASA-A), based on the theoretical model of Dorothea Orem ${ }^{(6)}$, was also used. This scale was translated and validated in Brazil and presented a Cronbach's alpha of 0.85 , and was entitled the Scale to Assess Self-care Capability - SASCC(10).

The SASCC consists in 24 items and allows Likert-type responses, whose score ranges from 1 (strongly disagree) to 5 (strongly agree). The total score of the scale comprises scores between 24 and 120 points, with higher scores indicating a better SCC. The scores can be categorized as follows: 24 to $40=$ very poor; 41 to $56=$ bad; 57 to $72=$ regular; 73 to $88=$ good; 89 to $104=$ very good; and 105 to $120=$ excellent $^{(10)}$.

A database was designed using EPI INFO 3.5.2 software through double data entry for the validation of the information collected. Data were exported and analyzed using the Statistical Package for Social Sciences software, version 18.

BCF was analyzed through the calculation of the frequency, means and related standard deviations. SCC analysis was made by calculating the minimum and maximum values, mean and standard deviation, in addition to the confidence intervals of the mean scores. The Cronbach's alpha served to assess the internal consistency of the SASCC ${ }^{(11)}$.

We used the chi-square test to compare the proportions between BCFs. The Student t test was used to compare variables between two groups, and the analysis of variance (ANOVA) was used to compare the variables between three or more groups $^{(11)}$.

The Poisson regression model was used to evaluate the relationship between BCF and SCC in the group under consideration. The Wald Test was applied to determine the statistical significance. The association of each factor with SCC was expressed in terms of a prevalence ratio (PR) with a confidence interval $(\mathrm{Cl})$ of $95 \%$. We made use of a $5 \%$ significance level for all tests ${ }^{(11)}$.

This study was approved by the National Research Ethics Committee under CAAE no. 11133712.2.0000.5192. All the individuals who made up the study sample agreed to participate voluntarily, and signed a consent form after clarification. They were assured of their privacy and their freedom in terms of refusing to participate, requesting further clarification and withdrawing consent at any stage of the research.

\section{RESULTS}

Table 1 summarizes the data related to FCB on the part of the study participants. We observed, by comparing ratios, the predominant profile of the group under consideration. 
Table 1 - Basic self-care conditioning factors among the study participants. Recife, 2013.

\begin{tabular}{|c|c|c|}
\hline $\begin{array}{c}\text { Basic self-care conditio- } \\
\text { ning factors }\end{array}$ & $\mathbf{n}$ & $\%$ \\
\hline \multicolumn{3}{|l|}{ Age } \\
\hline 50 to 60 years old & 30 & 48.4 \\
\hline 61 to 70 years old & 32 & 51.6 \\
\hline \multicolumn{3}{|l|}{ Gender } \\
\hline Male & 42 & 67.7 \\
\hline Female & 20 & 32.3 \\
\hline \multicolumn{3}{|l|}{ Skin (self-reported) } \\
\hline White & 29 & 46.8 \\
\hline Black & 7 & 11.3 \\
\hline Other & 26 & 41.9 \\
\hline \multicolumn{3}{|l|}{ Marital status } \\
\hline Married & 47 & 75.8 \\
\hline Divorced & 8 & 12.9 \\
\hline Widowed & 7 & 11.3 \\
\hline \multicolumn{3}{|l|}{ Education } \\
\hline Illiterate & 6 & 9.7 \\
\hline Lliterate & 3 & 4.8 \\
\hline Incomplete primary education & 12 & 19.4 \\
\hline \multicolumn{3}{|l|}{ I (1st to 3rd grade) } \\
\hline $\begin{array}{l}\text { Complete primary education I } \\
\text { (up to 4th grade) }\end{array}$ & 16 & 25.8 \\
\hline $\begin{array}{l}\text { Primary education II (5th to 8th } \\
\text { grade) }\end{array}$ & 13 & 21 \\
\hline Secondary education & 12 & 19.4 \\
\hline \multicolumn{3}{|l|}{ Employment } \\
\hline Retired & 37 & 59.7 \\
\hline Freelancer & 8 & 12.9 \\
\hline Employed & 12 & 19.4 \\
\hline Unemployed & 5 & 8.1 \\
\hline \multicolumn{3}{|l|}{ Individual monthly income } \\
\hline None & 5 & 8.1 \\
\hline$<\mathrm{R} \$ 678.00$ & 32 & 51.6 \\
\hline $\mathrm{R} \$ 678.00$ to $\mathrm{R} \$ 1,356.00$ & 15 & 24.2 \\
\hline$>\mathrm{R} \$ 1.356,00$ & 10 & 16.1 \\
\hline \multicolumn{3}{|l|}{ Family monthly income } \\
\hline$<R \$ 678.00$ & 13 & 21 \\
\hline $\mathrm{R} \$ 678.00$ to $\mathrm{R} \$ 1,356.00$ & 23 & 37.1 \\
\hline$>\mathrm{R} \$ 1.356,00$ & 26 & 41.9 \\
\hline
\end{tabular}

Primarily responsible for the family's income

\begin{tabular}{lll}
\hline Yes & 41 & 66.1 \\
No & 21 & 33.9 \\
Number of family members & & \\
1 & 4 & 6.5 \\
2 & 22 & 35.5 \\
3 & 15 & 24.2 \\
4 or more & 21 & 33.9 \\
\hline Socioeconomic Class & & \\
\hline B1 & 1 & 1.6 \\
B2 & 4 & 6.5 \\
\hline
\end{tabular}

\begin{tabular}{lll} 
C1 & 8 & 12.9 \\
C2 & 34 & 54.8 \\
D & 15 & 24.2 \\
\hline
\end{tabular}

Source: Authors' research

In terms of the group studied, SCC was categorized as shown in Table 2 . The average of the scores obtained through SASCC was 87.5 ( \pm 10.5 ), indicating a good SCC level in the group under consideration. We analyzed the internal consistency of the SASCC through Cronbach's alpha coefficient, calculated as 0.82 .

Table 2 - Description of self-care capability by categories in the studied group. Recife, 2013.

\begin{tabular}{lcc}
\hline \multicolumn{1}{c}{ Self-Care Capability } & n & $\%$ \\
\hline Very bad & 0 & 0 \\
Bad & 1 & 1.5 \\
Regular & 5 & 8 \\
Good & 21 & 33.9 \\
Very good & 32 & 51.6 \\
Excellent & 3 & 5 \\
\hline
\end{tabular}

In Table 3, we checked the mean score and the standard deviation of SCC for each of the BCF studied. According to the analyzed factors, there was no statistical significance between the mean scores relating to self-care capability.

Table 3 - Association between self-care capability and categories of basic conditioning factors. Recife, 2013.

\begin{tabular}{lcc}
\hline \multicolumn{1}{c}{$\begin{array}{c}\text { Basic Conditioning Fac- } \\
\text { tors }\end{array}$} & $\begin{array}{c}\text { Self-care } \\
\text { Capability }\end{array}$ & p-value \\
\hline Age & & \\
\hline 50 to 60 years old & $71.4 \pm 10.6$ & $0.200^{*}$ \\
61 to 70 years old & $74.3 \pm 6.5$ & \\
\hline Gender & & \\
\hline Male & $73.5 \pm 9.4$ & $0.503^{*}$ \\
Female & $71.8 \pm 7.6$ & \\
\hline Skin (self-reported) & & \\
\hline White & $74.0 \pm 5.9$ & $0.068 \dagger$ \\
Black & $65.7 \pm 9.8$ & \\
Other & $73.7 \pm 10.5$ & \\
\hline
\end{tabular}

Araújo RA, Silva TM, Ramos VP. Self-care during the coronary artery bypass graft preoperative period: a descriptive study. Online braz j nurs [internet] 2015 Dec [cited year month day]; 14 (4):499-507. Available from: http://www.objnursing.uff.br/ index.php/nursing/article/view/5088 


\begin{tabular}{|c|c|c|}
\hline \multicolumn{3}{|l|}{ Marital status } \\
\hline Married & $74.1 \pm 7.8$ & $0.063+$ \\
\hline Divorced & $67.6 \pm 12.2$ & \\
\hline Widowed & $77.2 \pm 2.1$ & \\
\hline \multicolumn{3}{|l|}{ Education } \\
\hline Illiterate & $73.9 \pm 4.5$ & $0.262 \dagger$ \\
\hline Lliterate & $79.2 \pm 3.8$ & \\
\hline $\begin{array}{l}\text { Incomplete primary educa- } \\
\text { tion I ( } 1 \text { st to } 3 \text { rd grade) }\end{array}$ & $73.8 \pm 7.2$ & \\
\hline $\begin{array}{l}\text { Complete primary education } \\
\text { I (up to 4th grade) }\end{array}$ & $70.6 \pm 7.5$ & \\
\hline $\begin{array}{l}\text { Primary education II ( } 5 \text { th to } \\
\text { 8th grade) }\end{array}$ & $69.7 \pm 9.8$ & \\
\hline Secondary education & $76.5 \pm 11.7$ & \\
\hline \multicolumn{3}{|l|}{ Employment } \\
\hline Retired & $74.0 \pm 6.6$ & $0.719+$ \\
\hline Freelancer & $70.7 \pm 9.4$ & \\
\hline Employed & $71.6 \pm 14.3$ & \\
\hline Unemployed & $71.8 \pm 7.1$ & \\
\hline \multicolumn{3}{|c|}{ Individual monthly income } \\
\hline None & $71.8 \pm 7.1$ & $0.093+$ \\
\hline$<\mathrm{R} \$ 678.00$ & $74.3 \pm 7.1$ & \\
\hline $\mathrm{R} \$ 678.00$ to $\mathrm{R} \$ 1,356.00$ & $71.5 \pm 10.3$ & \\
\hline$>\mathrm{R} \$ 1.356,00$ & $71.3 \pm 12.3$ & \\
\hline \multicolumn{3}{|l|}{ Family monthly income } \\
\hline$<\mathrm{R} \$ 678.00$ & $72.8 \pm 5.6$ & $0.358+$ \\
\hline $\mathrm{R} \$ 678.00$ to $\mathrm{R} \$ 1,356.00$ & $74.4 \pm 7.6$ & \\
\hline$>\mathrm{R} \$ 1.356,00$ & $71.4 \pm 10.9$ & \\
\hline \multicolumn{3}{|c|}{ Primarily responsible for the family's income } \\
\hline Yes & $73.4 \pm 10.0$ & $0.566^{*}$ \\
\hline No & $72.0 \pm 6.0$ & \\
\hline \multicolumn{3}{|c|}{ Number of family members } \\
\hline 1 & $72.3 \pm 5.3$ & $0.669+$ \\
\hline 2 & $71.1 \pm 10.1$ & \\
\hline 3 & $73.8 \pm 9.4$ & \\
\hline 4 or more & $74.3 \pm 7.5$ & \\
\hline \multicolumn{3}{|l|}{ Socioeconomic Class } \\
\hline B1 & $80.0( \pm 0.0)$ & $0.361 \dagger$ \\
\hline B2 & $76.2 \pm 16.5$ & \\
\hline C1 & $77.6 \pm 8.3$ & \\
\hline $\mathrm{C} 2$ & $71.5 \pm 7.5$ & \\
\hline $\mathrm{D}$ & $72.2 \pm 9.5$ & \\
\hline
\end{tabular}

*T student test. +Variance Analysis

Source: Authors' research

In Table 4, we see the Poisson model setting for SCC according to age and family monthly income. This model was generated from two previous models, in order to analyze the associations between greater SCC levels and BCFs; educational factors ( $p$-value $=0.390$ ) and marital status ( $p$-value $=0.065$ ) were excluded. As the table below indicates, increased age and a lower monthly family income were associated with higher SCC levels.

Table 4 - Poisson regression for self-care capability, according to the basic conditioning factors. Recife, 2013.

\begin{tabular}{|c|c|c|}
\hline Basic Conditioning Factors & p-value* & $\begin{array}{l}\text { Ad- } \\
\text { jus- } \\
\text { ted } \\
\text { ratio }\end{array}$ \\
\hline & & PR \\
\hline \multicolumn{3}{|l|}{ Age } \\
\hline 50 to 60 years old & & 1 \\
\hline 61 to 70 years old & & 1.46 \\
\hline Gender & 0.939 & \\
\hline Skin (self-reported) & 0.417 & \\
\hline Marital status & $<0.001$ & \\
\hline Education & 0.002 & \\
\hline Employment & 0.4 & \\
\hline Individual monthly income & 0.791 & \\
\hline \multicolumn{3}{|l|}{ Family monthly income } \\
\hline$<\mathrm{R} \$ 678.00$ & & 1.8 \\
\hline $\mathrm{R} \$ 678.00$ a $\mathrm{R} \$ 1,356.00$ & & 1.08 \\
\hline$>\mathrm{R} \$ 1,356.00$ & & 1 \\
\hline $\begin{array}{l}\text { Main responsible for the family's } \\
\text { income }\end{array}$ & 0.797 & \\
\hline Number of family members & 0.722 & \\
\hline Socioeconomic class & 0.395 & \\
\hline
\end{tabular}

*Wald test.

Source: Authors' research

\section{DISCUSSION}

The study aimed to relate BCFs to the SCC of individuals in the preoperatively period of $C A B G$, based on Orem's Self-Care Theory. Thus, the results obtained from the BCFs with regard to the studied group fit the descriptions in the literature regarding the predominant profile ${ }^{(3-4)}$. However, it highlights the low educational level and socioeconomic insecurity among the participants ${ }^{(12-14)}$. 
With respect to SCC, its average level was higher in the case of male participants, those who were widowed, were of a more advanced age, with just literate education level, retired, with a monthly individual income lower than R\$678.00 and a monthly family income of between $\mathrm{R} \$ 678.00$ and $\mathrm{R} \$ 1,356.00$.

It is noteworthy that a high SCC average on the part of the participants with the above characteristics, according to the theory adopted, should have enhanced self-care, while other individuals would require a more thorough evaluation in terms of the presence of self-care deficits, so they can receive adequate support in order to develop and improve this practice ${ }^{(1-2,4,8)}$. However, the results of the BCF and SCC differed from studies that identified these aspects with regard to individuals on dialysis or ventilatory support at home(1), and patients aged 65 or older living in urban $\operatorname{areas}^{(14)}$.

In individuals undergoing dialysis or ventilatory support at home, the SCC was described as being higher when there was social support, feelings of security and knowledge about the use of technology. However, there was no association between SCC and BCF and the factors of age, gender, education and income ${ }^{(1)}$.

In the study with patients aged 65 and older who live in urban areas, there was a high SCC level among the participants. This finding is associated with good health perception, regular physical activity and life satisfaction $^{(14)}$.

In both studies, the average SCC scores were $87.7( \pm 11.3)^{(1)}$ and $92.4( \pm 10.7)^{(14)}$. Considering that the average obtained in the study group was $87.5( \pm 10.5)$, we can consider that individuals in the preoperative CABG period are able to develop and improve their selfcare practices.
This finding can be corroborated because the two aforementioned studies were conducted in developed countries with a high human development index. In addition, the individuals studied were in an unfavorable situation, away from their families, frequently relying only on the support provided by the hospital, revealing an ability to maintain their health and well-being, even before the impact of cardiovascular disease ${ }^{(6,15)}$.

However, SCC must be contextualized to the reality of the studied group. In the case of this research, the association between SCC and factors such as age, income and education stand out, even if the latter factor was not statistically significant in the multivariate analysis.

Thus, the aforementioned factors, although they must be treated with care in the case ofthe group under consideration, are important for the planning of nursing care, as well as for the exploration, development and maintenance of self-care practice in patients with cardiovascular problems ${ }^{(16)}$.

Particularly with regard to education, the previous studies have highlighted that greater self-care is associated with better education, better communication and greater understanding. These characteristics favor the achievement of self-care practices ${ }^{(12-13)}$, revealing the importance of education of individuals in the planning of nursing interventions.

Another highlighted fact in terms of the group studied, was that greater age and lower monthly family income were associated with a higher SCC. This indicates that, in this particular group, there was the development of adaptive and coping skills relating to the cardiovascular disease process, even taking into the account a socioeconomic disadvantage $\mathrm{e}^{(3,16)}$.

This association needs to be more deeply studied, preferably by a research study incor- 
porating greater statistical power, or involving a qualitative approach in terms of the intrinsic and extrinsic factors of the individuals concerned which could enhance adaptation and coping in critical situations - a case exemplified by resilience.

However, we observe here that there is the possibility of links between promotion, prevention and rehabilitation for patients in the CABG preoperative period ${ }^{(15)}$ with the recognition of BCF and SCC, based on a particular theory of nursing ${ }^{(6)}$.

The studied factors favor a holistic view of the group, determining its specific characteristics and needs; thus, it would help provide information for actions involving the social inclusion and historicity of the participants, decentralizing this performance from the medical team and from technology $y^{(6,15)}$.

Therefore, we observe the need for health education for individuals in the CABG preoperative period and we highlight the uniqueness and autonomy of these individuals in terms of self-care practices ${ }^{(4,16-17)}$.

Anyone can achieve greater SCC throughout life to a lesser or greater degree, and be able to perform actions for self-care. These could improve results in the intra and postoperative stages, and also prevent life-threatening situations from emerging ${ }^{(6-18)}$.

It is worth mentioning, also, that this study has limitations inherent in its nonexperimental design due to the non-randomized sampling and low educational level of the participants, restricting application of the results to similar groups. In addition, the instruments used had the purpose of extracting the specific information the researchers wanted to obtain, not what the participants wanted to express.

\section{CONCLUSION}

In terms of the association between BCF and SCC, the following factors stood out among the participants: age, marital status, education and family monthly income. We stress that better SCC was associated with age and family income in the studied group.

In this context, there is the possibility of applying Orem's nursing theoretical model with regard to patients undergoing the CABG preoperative period. Such an application favors integration between research, practice and theory, and thus contributes to the development and the autonomy of the work process in nursing.

This application may be anchored both in BCFs and SCC as long as they are contextualized with regard to the target site and population. To strengthen the theoretical model used, we emphasize the need to address other aspects contained in it, to make it viable with regard to clinical nursing practice.

The research that addresses SCC through mixed methods should also be encouraged in order to understand issues intrinsic to each individual, favoring the recognition of factors that stimulate or hinder self-care practices.

Finally, even with the socio-economic precariousness pointed out by BCF respondents, we confirmed the development of SCC in the group studied. This involved the clinical practice of nursing, the planning of dialogued interventions that respect the historicity, social inclusion and limitations of the assisted individuals and the aim for a better quality of life after surgery.

\section{REFERENCES}

1. Fex A, Flensner G, Ek AC, Söderhamn O. Self-care agency and perceived health among people us- 
ing advanced medical technology at home. J Adv Nurs. 2012 Apr;68(4):806-15.

2. Dessotte CAM, Dantas RAS, Schmidt A, Rossi LA. Qualidade de vida relacionada à saúde de sujeitos internados, decorrente da primeira síndrome coronariana aguda. Rev Latino-Am Enfermagem. 2011 Oct;19(5):1106-13.

3. Tu JV, Ko DT, Guo H, Richards JA, Walton N, Natarajan MK, et al. Determinants of variations in coronary revascularization practices. CMAJ. 2012 Feb;184(2):179-86.

4. Galdeano LE, Rossi LA, Dantas RAS. Deficient knowledge nursing diagnosis: identifying the learning needs of patients with cardiac disease. Int J Nurs Terminol Classif. 2010 JulSep;21(3):100-7.

5. Raimondo ML, Fegadoli D, Méier MJ, Wall ML, Labronici LM, Raimondo-Ferraz MI. Produção científica brasileira fundamentada na Teoria de Enfermagem de Orem: revisão integrativa. Rev Bras Enferm. 2012 Jun;65(3):529-534.

6. Taylor SG, Renpenning K. Self-care science, nursing theory, and evidence-based practice. New York: Springer Publishing; 2011.

7. Polit DF, Beck CT. Essentials of nursing research: appraising evidence for nursing practice. $7^{\mathrm{a}} \mathrm{ed}$. Porto Alegre: Artmed; 2011.

8. Sá MP, Silva DO, Lima EN, Lima RC, Silva FP, Rueda FG, et al. Postoperative mediastinitis in cardiovascular surgery postoperation. Analysis of 1038 consecutive surgeries. Rev Bras Cir Cardiovasc. 2010 Jan-Mar;25(1):19-24.

9. Associação Brasileira de Empresas de Pesquisa [Internet]. Critério de Classificação Econômica Brasil; 2012 [atualizado 2012 Set 11, citado 2012 Set 12]. Disponível em: https://www.abep.org/ codigosguias/ABEP_CCEB.pdf.
10. Silva JV. Adaptação cultural e validação da escala para avaliar as capacidades de autocuidado. Rev Eletrônica Acervo em Saúde. 2013 Jun-Dez;5(2):426-47.

11. Agresti A, Finlay B. Statistical methods for the social sciences. 4ª ed. Porto Alegre: Penso; 2012.

12. Visaya MA. Hemodialysis patients' perceptions of home hemodialysis and self-care. J. CANNT J. 2010 Apr-Jun;20(2):23-8.

13. Macabasco-O'Connell A, DeWalt DA, Broucksou KA, Hawk V, Baker DW, Schillinger D, et al. Relationship between literacy, knowledge, self-care behaviors, and heart failure-related quality of life among patients with heart failure. J Gen Intern Med. 2011 Sep;26(9):979-86.

14. Sundsli K, Söderhamn U, Espnes GA, Söderhamn O. Ability for self-care in urban living older people in southern Norway. J Multidiscip Healthc. 2012 Mar;5:85-95.

15. Malta DC, Merhy EE. O percurso da linha do cuidado sob a perspectiva das doenças crônicas não transmissíveis. Interface. 2010 Sep;14(34):593606.

16. Vitor AF, Lopes MVO, Araujo TL. Teoria do déficit de autocuidado: análise da sua importância e aplicabilidade na prática de enfermagem. Esc Anna Nery Enferm. 2010 Set;14(3):611-6.

17. Sena AC, Nascimento ERP, Maia ARCR. Prática do enfermeiro no cuidado ao paciente no pré-operatório imediato de cirurgia eletiva. Rev Gaúcha Enferm. 2013 Set;34(3):132-7.

18. Araújo RA, Oliveira NB, Barbosa HSC, Bezerra SMMS. Population affected by mediastinitis in a university hospital in Recife-PE: a retrospective study. Online braz j nurs [periodic online]. 2012 Dec [cited 2014 oct 23]; 11 (3): 789-99. Available from: http://www.objnursing.uff.br/index.php/ nursing/article/view/3604. 
All authors participated in the phases of this publication in one or more of the following steps, in According to the recommendations of the International Committee of Medical Journal Editors (ICMJE, 2013): (a) substantial involvement in the planning or preparation of the manuscript or in the collection, analysis or interpretation of data; (b) preparation of the manuscript or conducting critical revision of intellectual content; (c) approval of the versión submitted of this manuscript. All authors declare for the appropriate purposes that the responsibilities related to all aspects of the manuscript submitted to OBJN are yours. They ensure that issues related to the accuracy or integrity of any part of the article were properly investigated and resolved. Therefore, they exempt the OBJN of any participation whatsoever in any imbroglios concerning the content under consideration. All authors declare that they have no conflict of interest of financial or personal nature concerning this manuscript which may influence the writing and/or interpretation of the findings. This statement has been digitally signed by all authors as recommended by the ICMJE, whose model is available in http://www. objnursing.uff.br/normas/DUDE_eng_13-06-2013.pdf
Received: $11 / 03 / 2014$

Revised: 10/07/2015

Approved: 10/08/2015 